\title{
Clean Energy Development and Its Policy in China
}

\author{
Zhi-Xing XIAO', a , An XU', b \\ ${ }^{1,2}$ Jing De Zhen Ceramic Institute, Jingdezhen, jiangxi provence, China

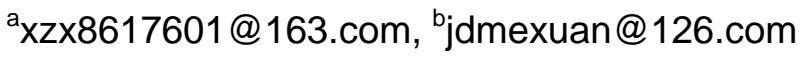

Keywords: Clean Energy, Financial Support, Tax Policy, Subsidies.

\begin{abstract}
For the international and environment pressure, it is urgent for China to reduce pollutant and greenhouse gases. One of the very useful method is to use clean energy. But for the complicated technology and high price of clean energy, it is very difficult for clean energy industry to self-commercialized. China government should take many efforts to develop clean energy industry. The practicable methods are tax policy, subsidies policy, financial support and international cooperation.
\end{abstract}

\section{Introduction}

Clean energy is also known as the energy does not emit pollutants, including hydropower, nuclear energy, solar energy, wind energy, geothermal energy, tidal energy, bio-energy, most of them are converted to electric power to use.

Conventional energy sources such as coal, petroleum, natural gas have been the main energy sources for the world during the past days. But whit their byproduct and the environmental pressure, clean energy and renewable energy sources have been paid more attention in the world.

China,the second greatest economic bodies in the world also facing with the same problems, has to make great strength to address environmental pollution. Since launching its open-door policy and economic reform in late 1978, especially in 1992 made marketing economic goal, China has made great progress in economic. But the main energy sources in China are coal. As the main fuel, it makes heavy environmental pollution and emits large amount of $\mathrm{CO}_{2}$ gas which produce greenhouse effect. So producing and using clean clean energy sources also become important things for China.

Clearly, China can't afford to continue its economic growth under the condition of energy resources and environment pressure. The first reason is that there relative shortage of oil and gases resources for fuel in China. Coal is the most abundant and cheapest energy resources. But using coal as fuel will produce serious pollution problems and emit large amount of carbon dioxide gas. Recently ,with the weather become cool, Harbin, a city in north China, begins to supply heat. But immediately there many haze days for using coal as fuel. The second reason is that though oil and nature gases are kinds of fossil energy with less pollution than coal.There is short of oil and nature gases per capita in China. The third reason is that since 2004 China having been the second heaviest carbon emissions country in the world. On the Copenhagen Climate Change Conference in December 2009, Chinese government had made commitment to cut $40-45 \%$ in carbon emission intensity until 2020 contrast to in 2005. It is essential and urgent for China apply more clean energy. These concern and pressures have sparked China's determination to improve energy efficiency and increase the use of clean energy in order to help its transition to a low carbon economy.

According to the Energy Information Agency (EIA), in 2004, China accounted for 17\% of world total carbon dioxide emissions.And the EIA expected that if current energy trends continue China carbon dioxide emissions would increase to $40 \%$ of the world total between 2005 and 2030. In 2009, China Daily reported that totaling almost one million babies are born with defects cases a year. Lung cancer in China has also become the common fatal disease since lung cancer have risen $465 \%$ over the past 30 years. In April 2008, the Chinese Ministry of Health reported that the rise in deaths of lung cancer was directly related to environmental consequences.Because of these reasons, it is essential that the China begin to pay more attention to clean energy and try to use more clean 
energy.

But in practice, there are a lot of difficulties and obstacles to be addressed. Such as the high cost of clean energy production, the investment in clean energy industry with high risks, the technology etc. In the following chapters we will discuss these problems and try to find practical methods to address them.

\section{Obstacles on the Development Process of Clean Energy in China}

In current, the clean energy industries have developed rapidly in China . But there are sill lot of problems during the development of clean energy .Such as the small market scale,high cost,inefficient technology,equipment etc.

\section{Low Level Technologies on the Whole}

There has been insufficient investment in R\&D and lack of high-technical human resources in China. The process of clean energy technology development and commercialization can be divided into technological innovation research phase, commercialization, diffusion and promotion phase (Sagar and Holdren, 2002; Sagar and Zwaan, 2006). Especially in the innovation phase clean energy technologies progress needs huge $R \& D$ investment. Industry countries have achieved great success in the field of clean energy for their adequate R\&D investment. The advanced technologies for clean energy tightly controlled by industry countries, even with the high price it is difficult to obtain critical technologies. High-power wind turbines, biomass direct combustion power generation boilers, poly-silicon furnace and a new generation of technology -based nuclear device basically dependent on imports. China bought technical equipment but failed induce technology diffusion, Lack of effective digestion, absorption and re-innovation. There is large gap in clean technology between China and industry countries. Several key technical areas of clean energy in China are highly dependent on foreign countries. For example, the current popular advanced megawatt-class wind turbine, biomass direct combustion power generation boilers, poly-silicon materials required by solar generation are all imported from developed countries.

\section{Clean Energy Product with Relative High Cost and Lack of Competitive Power}

Currently, the main problem which most clean energy industries facing is still high cost and weak competitive power. The only cheap clean energy resources is nuclear power. But this kind energy is opposed by many industry countries for its unsafety. Others such as solar energy and wind energy all will have to face to the high cost and their unstable production characters in generating electricity or heat. It will cost large to invest a wind energy power station or solar power station.

Clean energy production costs are usually influenced by the factors of production technology, equipment, the scale of the market. Without consideration about the environment cost, clean energy production cost is much higher than that of fossil energy. The power generation cost can be compare as follow, assume that coal electricity cost is 1 , then the cost of small hydro power generation is about 1.2 times that of coal, biomass power generation (gas to generate electricity cost 1.5 times as much as the coal), wind cost is 1.7 times of the coal, the cost of photovoltaic power generation for coal-fired power 11 - 18 times[1].So these clean energy product is lack of competitive power and self-commercialization ability.

\section{Inadequate Clean Industry Investment and Few Financing Channels}

The initial investment cost of clean energy is more than that of traditional energy. Clean energy investment payback period is long and the risk is high, so it is less attractive to investors. So far, there has been no standard in the fiscal budget at various levels for clean energy project in China. The clean energy project being set up is similar to conventional energy financing channel. Under the current condition of our China, due to the clean energy market uncertainty, the domestic bank loan approval is strict. And obtaining loans especially for more than 15 years of long-term loans is very difficult. From the international capital market, the negotiation process obtaining long-term loan from international financial organizations are complicated and management procedures are 
tedious. In addition, the clean energy technology is a kind of high technology. The initial investment on equipments and research is very large. The clean energy industry development is high risk and the clean energy market is uncertainty. The investors are not sure about clean energy's future income. So rational investors are difficult to make decision to invest in clean energy enterprise or on clean energy R\&D. Therefore, China's clean energy industry is lack of funds. Financing become one of the difficulties in the development of clean energy.

\section{The Small Market Scale and Public's Low Consumption Desire}

In China the clean energy market is small. The clean energy market scale determines its economic performance, and the scale of the market influence the clean energy cost. In turn, the average cost of the clean energy influence the scale of the market.

One challenge comes from the continued dominance of energy intensive industries, which has been identified as a contributing factor in China's inability to meet its first short-term energy intensity reduction target[2]. Recognizing this, the National Development and Reform Commission(NDRC) has announced plans in 2010 to raise power prices for some energy-intensive firms in renewed efforts to control the expansion of such energy-guzzling and pollutive industries. Another key challenge for China is that there is lack of advanced technology for national grid to accept the clean energy power for their instability and higher price. So national grid unwill to accept the clean energy power. The third challenge for China is that there are few clean energy products unified technical specifications, quality supervision system, information service in China .The clean energy's technology and information is often outdate. The disorder state of the market disturbed the market development.

\section{The Practicable Solutions for the Development Clean Energy Industry in China}

At present, China has been one of the largest carbon emitter in the world. The total energy consumption in China is very close to that of USA. China will soon surpass the United States as the first major energy consumer. The development of clean energy in energy structure optimization, energy security, increasing the supply of energy, reduce environmental pollution is very important for China. To solve these problems some tactics should be applied by China government and society.

\section{Government Support}

The previously mentioned clean energy industry's product is high cost and lack of competitive power. But for the clean energy industry is effective in addressing air pollution and greenhouse effect problem. Government should provide various supporting policies for the development of clean energy industry. First the government could make the regulation to incentive the enterprises to consume or produce clean energy .The methods are taxes or subsidies or quota obligation. The government could reduce the corporation's income tax sharply which produce clean energy even make subsidies to these enterprises. At the same time the government could require the enterprise which produce energy-intensity based to have a using clean energy quota obligation.

The government could set up a Clean Development Mechanism Fund to help the clean energy enterprises invest in R\&D or supply subsidies. The Clean Development Mechanism Fund's capital could come from extra tax on the enterprises that energy-intensity based but not rely on the clean energy sources.

\section{Financial Support}

Commercial bank is one of the main financing channel of clean energy enterprises in China. Commercial banks should actively support the clean energy industry's development. Commercial bank could use its regional advantages to steadily expanding the field of clean energy credit support range. Of course commercial bank's credit can't be used as R\&D capital. The credit can only be used in the clean energy development's mature stage. The policy bank National Development Bank should take the duty in the process of clean energy $R \& D$ and innovation. The National 
Development Bank should play an important role in the course of clean energy technologies development and commercialization. National Development Bank could provide free-interest loans to the clean energy enterprises.

Direct private investment should be encouraged to promote clean energy industry. The government could encourage clean energy technology companies to raise money through stock market.

\section{Enhance International Cooperation}

Though China government wants to develop clean energy eagerly and there are abounded clean energy resources in China. But the clean energy technology and equipments are always in-advanced or outdate. The Chinese clean energy enterprises usually is lack of the capacity in R\&D or innovation. So it is very important for China to strengthen international cooperation in techniques and management .At the same time, intellectual property rights should be protected to gain the update techniques.

\section{Conclusion}

It is urgent for China to reduce pollutant and greenhouse gases for the reason international and environment pressure. One of the very useful methods is to use clean energy. But for the complicated technology and high price of clean energy, it is very difficult for clean energy industry to self-commercialized. China government should take many efforts to develop clean energy industry. The practicable methods are tax policy which the government could reduce the clean energy enterprise's income tax sharply even grant subsidies to these enterprise. At the same time , the government could impose extra tax on the traditional energy power company. Government could use clean energy quota obligation to the energy-intensity enterprises. At the same time government should encourage the financial institutes to supply credit to clean energy enterprises to do $R \& D$ or innovation. To cooperate with international institutes in innovation and $R \& D$ is very important for China.

\section{Reference}

[1] Fu liping (2012) "On the Drive Mechanism of Chinese Clean Energy Development", Ecological economy, (2): 76 - 79.

[2] "China's Green Energy and Environmental Policies", Elizabeth C. Economy, Council on Foreign Relations, April 2010

[3]Delmas, M.A., Montes-Sancho, M.. Voluntary agreements to improve environmental quality: Symbolic and substantive cooperation. Strategic Management Journal, 31 (2010)575-601.

[4] Fu liping,On the Drive Mechanism of Chinese Clean Energy Development" , Ecological economy, 2 (2012) 76-79.

[5] Ragwitz, M., and A. Miola, "Evidence from R\&D Spending for Renewable Energy Sources in the EU”, Renewable Energy, Vol. 30, Issue 11, (2005)pp.1635-1647.

[6] Sagar, A.D., and B. Zwaan, "Technological Innovation in the Energy Sector", Energy Policy, Vol. 34, Issue 17, (2006)pp. 2601-2608.

[7] Shi, L.S., “China's Renewable Energy Development Strategy', Sino-Global Energy, Vol. 15, Issue 3, (2010)pp. 29-32. 